\title{
Review
}

\section{The politics of sincerity: Plato, frank speech and democratic judgment}

\author{
Elizabeth Markovits \\ Pennsylvania State University Press, University Park, PA, x $+234 \mathrm{pp}$., \\ $£ 39.95 / \$ 45.00$, ISBN: 978-0271033396
}

Contemporary Political Theory (2013) 12, e5-e9. doi:10.1057/cpt.2011.38

In The Politics of Sincerity: Plato, Frank Speech and Democratic Judgment, Elizabeth Markovits constructs a critique of what she terms the contemporary politics of 'hyper-sincerity', understood as 'our democratic obsession with sincerity and truth-telling' (p. 15). Markovits argues that the quest for sincerity in politics is a dangerous distraction from the difficult task of political judgment: it is dangerous insofar as it risks the overexposure of our private lives to public scrutiny; it distracts us from the task of political judgment insofar as the authoritative standpoints constructed by rhetorical tropes of hyper-sincerity attempt to foreclose debate. Contending that deliberative theory, with its own emphases on sincerity and truth-telling, is not equipped to critique the vicissitudes of the politics of sincerity, Markovits envisions her project as a continuation of the recent attempts by Danielle Allen and Bryan Garsten to rehabilitate rhetoric and rhetorical forms of speech as valuable types of democratic discourse. With these concerns in mind, Markovits turns to Plato's dialogues to identify irony and mythmaking as alternatives to sincerity, and to Hannah Arendt and Judith Butler to articulate a conception of trustworthiness that tracks publicly displayed character, rather than the interior life of citizens.

Chapters 1 and 2 seek to establish the dangers of the politics of sincerity for both contemporary and ancient democratic politics. Beginning with Habermas' discourse ethics, Markovits argues that the distinction he draws between sincerity and truth claims collapses in practice: explicit claims to sincerity entail implicit claims to truth. This connection manifests itself in the two 'master tropes' of hyper-sincerity Markovits identifies: the cult of plain speech and the realist rhetorical style. Both construct objective, authoritative views of the world that seek to close the discursive space necessary for democracy. Chapter 2 demonstrates that 'our democratic obsession with sincerity and truth-telling'

(C) 2013 Macmillan Publishers Ltd. 1470-8914 Contemporary Political Theory Vol. 12, 1, e5-e9 www.palgrave-journals.com/cpt/ 
is not only our obsession - it is one we share with the citizens of democratic Athens. Markovits establishes this claim through an analysis of the evolution and devolution of parrhēsia (frank speech) in Athenian democratic discourse: while parrhēsia originates, Markovits argues, as a democratic norm guarding against deceptive speech, the claim that one is speaking frankly can itself become a rhetorical trope - a type of 'rhetoric of anti-rhetoric'. Taking Cleon's speech in the Mytilenian debate as paradigmatic, Markovits illustrates how the rhetorical claim to frank speech undermines deliberation by demanding that the audience accept the speaker's advice uncritically.

Chapters 3 and 4 articulate conceptions of irony and mythmaking as alternatives to frank speech. Chapter 3 develops an interpretation of Socratic irony in the Gorgias as a method for sparking reflection in both Socrates' interlocutors and the readers of the dialogue. In reading Socrates' claim to practice politics as ironic, for example, Markovits highlights the aporetic dimension of Socratic irony: it demands that the reader attempt to understand what the seemingly apolitical Socrates means by claiming to be a politikos, which in turn raises the larger question of what it means to practice politics in the first place. Chapter 4 argues that we should read the myths of the Republic as highlighting the need for political judgment, rather than as justifications for authoritarian rule. The chapter concludes with a reading of the dialogue itself as a type of myth, likening it to one of the 'summoners' Socrates identifies as capable of simultaneously evoking competing interpretations.

While Plato points us to alternatives to frank speech, Markovits ultimately worries that his 'focus on the interior life ... might still inadvertently encourage the politics of sincerity' (p. 173). To provide an alternative ethic, Markovits turns to Hannah Arendt's conception of political judgment and its focus on public appearances over true intentions. For Markovits, the Arendtian account of democratic deliberation that flows from acknowledging the human condition of plurality demands both accounting for the viewpoints of others and placing our own viewpoints in public where they can be held to account. Claims of sincerity, in contrast, seek to preclude the subjection of one's viewpoint to public accountability through the guise of truth. Informed by this Arendtian approach, Markovits suggests 'trustworthiness' as an alternative to sincerity as a criterion for evaluating our representatives. Trustworthiness, unlike sincerity, focuses on one's publicly displayed character, rather than on one's interior life.

There are two main threads of argumentation in the book that for me raised questions about the usefulness of the Platonic dialogues for both Markovits's project in particular and as a resource for democratic theorizing more generally. First, Markovits motivates her move from Plato to Arendt with an Arendtian argument about the dangers of public scrutiny of the interiority of the individual citizen. Given these concerns, however, one might ask why the author turns to Plato, for whom politics is inextricably linked with soulcraft, in 
the first place. The concept of irony has enjoyed a rich history in the nineteenth and twentieth centuries; one hardly needs to reach back to Socrates and Plato to think about the role of irony in politics. Likewise, Arendt's own concern with storytelling would seem a more natural fit with her contemporary concerns than Socratic/Platonic mythmaking.

Socrates' deployment of irony, moreover, drives those interlocutors who recognize and denounce it - Thrasymachus, Callicles and Alcibiades - to seek the 'true' Socrates behind the mask, an urge that is vividly depicted in Alcibiades' speech in Plato's Symposium. From this perspective, Socratic irony does seem to provoke reflection, but it provokes exactly the type of reflection that Markovits thinks we contemporary democrats should avoid. For me this raised the question of whether this dynamic is particular to Socratic irony. If so, I wonder whether there might be an alternative conception/practice of irony that might deflect, rather than exacerbate, this turn toward interiority, one that would be better suited to avoiding the dangers of the politics of sincerity Markovits identifies.

Second, Markovits reads Plato, following the important work by Peter Euben and Sara Monoson, as deeply entangled in the democratic thought and practice of his day. Within this framework, Markovits develops an insightful reading of the connection between the myth of the metals and the Athenian myth of autochthony, one that she argues is geared toward stimulating the individual political judgment of the dialogue's readers. Rather than attempting to pass off the myth as true to the citizens of Kallipolis, Markovits argues that it functions in the dialogue by calling attention to the fact that its Athenian readers may already believe a very similar story. This juxtaposition highlights the strangeness of this Athenian belief, and serves as an 'indirect elenchus' (p. 139). While I agree that the myth invites critical reflection, I wonder how open the parameters are for this critical reflection within the dialogue. In the Menexenus, for example, Socrates offers a democratic interpretation of the autochthony myth: 'We and our fellow-citizens, all brothers sprung from one mother, do not think it right to be each other's slaves or masters. Equality of birth (isogonia) in the natural order makes us seek equality of rights (isonomia) in the legal and defer to each other only in the name of reputation for goodness and wisdom' (238e5-239a4). ${ }^{1}$ The myth of the metals does ask us to reflect critically on the Athenian myth of autochthony, but I would argue that it does so in a way that severs this link between isogonia and isonomia. All citizens of Kallipolis might be born of the earth, but that does not, in itself, justify a democratic political arrangement. In Kallipolis, only those who have been mixed with gold are competent to exercise political power; in democratic Athens, in contrast, isonomia meant that all adult, male citizens could exercise such political power, and it is this isonomic arrangement that comes under heavy criticism in Book 8 of the dialogue. 
Markovits readily admits that the myth possesses such an aristocratic dimension while choosing to emphasize its stimulation of a more open-ended form of critical reflection. I would have liked to have heard more, however, about why the particular type of judgment and reflection promoted by reading the dialogue is democratic. Towards the end of her chapter on the Republic, for example, Markovits maintains the following: 'The Myth of Er makes plain this need for judgment; in turn, judgment can help sustain a democratic character that neither panders to nor claims complete autonomy from social convention' (p. 158). Taken on their own, both of these statements make perfect sense. Taken together, however, I do not see the necessary connection. In the Republic, whether one judges well or poorly depends on which station one occupies along the divided line Socrates delineates. The image of the divided line is itself an acknowledgement that there are different perspectives from which to judge the phenomena of the world. But there is little ambiguity, I would argue, as to which perspectives are better or worse. Within this epistemological framework, democratic judgment is faulty because the demos is confined to the realm of opinion (doxa).

This is not to argue, necessarily, that we cannot turn to Plato as a resource for democratic theorizing. But for me it raises the question of what we mean by 'democratic' when we attempt to read Plato in this way. I agree with Markovits that the Republic is more aporetic than traditional interpretations of the dialogue have acknowledged. I think that her reading of the dialogue as itself a type of myth is an insightful way of making this point. And I would concur that 'openness' is one of the criteria that we use in describing a political regime as democratic. Nonetheless, as my comments above indicate, I am skeptical that the dialogue is as open-ended as Markovits makes it out to be. I would insist, moreover, that central to the Athenian conception of democracy was the actual exercise of political power by the demos combined with the belief that the demos, qua demos, was a competent judge of political matters. This is an issue about which there is little aporia in the Platonic dialogues.

Overall, the Politics of Sincerity is an engaging book, one that urges its readers to return to the Platonic dialogues with a fresh set of concerns in mind, and for this reason will be of interest to those working within the fields of both contemporary democratic theory and ancient Greek political thought (and especially to those working at the intersection of the two). The book is also deeply rooted in contemporary democratic politics and political culture. I found one of its most admirable traits to be the way that Markovits seamlessly transitions between analyses of The Daily Show and John McCain's 2008 presidential campaign, to mention but two examples, to the academic literature on deliberative democracy, rhetoric and Plato. Markovits's readings of Plato's Gorgias and Republic are also rewarding. For two dialogues for which there is 
certainly no dearth of secondary literature, Markovits's interpretations are fresh and provocative, while remaining grounded in the historical context within which Plato was writing.

\section{Note}

1 Ryan translation, in Plato (1997).

\section{Reference}

Plato (1997) Complete Works, J. Cooper (ed.). Indianapolis, IN: Hackett Publishing.

John Lombardini

The College of William and Mary, Williamsburg VA, USA 